\title{
Characteristics Associated with Patient-Centered Medical Home Capability in Health Centers: A Cross-Sectional Analysis
}

\author{
Yue Gao, MPH' ${ }^{7}$, Robert S. Nocon, $M H^{7}$, Kathryn E. Gunter, MPH, MSW' , Ravi Sharma, PhD², \\ Quyen Ngo-Metzger, MD, MPH ${ }^{3}$, Lawrence P. Casalino, MD, PhD ${ }^{4}$, and Marshall H. Chin, MD, MPH ${ }^{1}$
}

\begin{abstract}
'Section of General Internal Medicine, Department of Medicine, The University of Chicago, Chicago, IL, USA; ${ }^{2}$ Bureau of Primary Health Care, Health Resources and Services Administration, U.S. Department of Health and Human Services, Rockville, MD, USA; ${ }^{3}$ U.S. Preventive Services Task Force Program, Agency for Healthcare Research and Quality, U.S. Department of Health and Human Services, Rockville, MD, USA; ${ }^{4}$ Department of Healthcare Policy and Research, Weill Cornell Medical College, New York, NY, USA.
\end{abstract}

BACKGROUND: The patient-centered medical home (PCMH) model is being implemented in health centers (HCs) that provide comprehensive primary care to vulnerable populations.

OBJECTIVE: To identify characteristics associated with HCs' PCMH capability.

DESIGN: Cross-sectional analysis of a national dataset of Federally Qualified Health Centers (FQHCs) in 2009. Data for PCMH capability, $\mathrm{HC}$, patient, neighborhood, and regional characteristics were combined from multiple sources.

PARTICIPANTS: A total of 706 (70\%) of 1014 FQHCs from the Health Resources and Services Administration Community Health Center Program, representing all 50 states and the District of Columbia.

MAIN MEASURES: PCMH capability was scored via the Commonwealth Fund National Survey of FQHCs through the Safety Net Medical Home Scale (0 [worst] to 100 [best]). $\mathrm{HC}$, patient, neighborhood, and regional characteristics (all analyzed at the $\mathrm{HC}$ level) were measured from the Commonwealth survey, Uniform Data System, American Community Survey, American Medical Association physician data, and National Academy for State Health Policy data.

KEY RESULTS: Independent correlates of high PCMH capability included having an electronic health record (EHR) (11.7-point [95\% confidence interval, CI 10.213.3]), more types of financial performance incentives (0.7-point [95\% CI 0.2-1.1] higher total score per one additional type, maximum possible $=10$ ), more types of hospital-HC affiliations (1.6-point [95\% CI 1.1-2.1] higher total score per one additional type, maximum possible $=6$ ), and location in certain US census divisions. Among HCs with an EHR, location in a state with statesupported $\mathrm{PCMH}$ initiatives and $\mathrm{PCMH}$ payments was associated with high PCMH capability (2.8-point, 95\% CI 0.2-5.5). Other characteristics had small effect size based on the measure unit (e.g. 0.04-point [95\% CI 0-0.08] lower total score per one percentage point more minority patients), but the effects could be practically large at the extremes.

Electronic supplementary material The online version of this article (doi:10.1007/s11606-016-3729-8) contains supplementary material, which is available to authorized users.

Received December 14, 2015

Revised April 18, 2016

Accepted April 25, 2016

Published online May 23, 2016
CONCLUSIONS: EHR adoption likely played a role in HCs' improvement in $\mathrm{PCMH}$ capability. Factors that appear to hold promise for supporting $\mathrm{PCMH}$ capability include a greater number of types of financial performance incentives, more types of hospital-HC affiliations, and statelevel support and payment for PCMH activities.

KEY WORDS: health center; medical home; vulnerable populations; disparities; financial incentives.

$J$ Gen Intern Med 31(9):1041-51

DOI: $10.1007 / \mathrm{s} 11606-016-3729-8$

(c) Society of General Internal Medicine 2016

I n 2014, 1278 Health Resources and Services Administra1 tion (HRSA)-supported Health Center Program grantees served 22.9 million patients, constituting a critical portion of the primary care safety net for vulnerable patients. ${ }^{1}$ Organizations such as the HRSA have encouraged and supported HC adoption of the patient-centered medical home (PCMH) mod$\mathrm{el}^{2-4}$ which aims to provide comprehensive and coordinated patient-centered care, deliver accessible services, and focus on quality. Therefore, it has the potential to improve the care experience and the quality of care, and to reduce emergency room visits, hospital admissions, and total cost. ${ }^{5-8}$

It is important to identify potential ways to increase the capability of HCs to serve as PCMHs, and specifically to identify key characteristics associated with PCMH capability in HCs. Previous studies have examined similar questions in a variety of settings using different outcomes, including: medical home processes, ${ }^{9-11}$ capacity, ${ }^{12,13}$ and infrastructure, ${ }^{14,15}$ care management processes, ${ }^{16}$ structural capabilities, ${ }^{17,18}$ program implementation progress index, ${ }^{19}$ and the percentage point or the level of recognition achieved on the National Committee on Quality Assurance (NCQA) PCMH standards. $^{20-23}$ These studies have identified a few characteristics associated with medical home capability, such as practice size, type, and ownership, external incentives, organizational relationships, health information technology (HIT), and patient and neighborhood demographics and socioeconomic characteristics. Other studies have identified characteristics associated with individuals' access to care that are consistent with the 
principles of the medical home, such as patient age, race/ ethnicity, insurance type, household income, primary language, disease burden, and neighborhood characteristics. ${ }^{24-26}$

However, these studies are limited in their ability to identify specific characteristics associated with PCMH capability in HCs and the magnitude of their impact. Most studies have focused on non-HCspecific settings such as physician organizations, family medicine practices, and Veterans Health Administration clinics, ${ }^{9-22}$ which differ from HCs in financing, patient populations, payer mix, disease burden, and surrounding communities. To our knowledge, only one study has been conducted in HCs, among 50 safety net clinics in New Orleans. ${ }^{23}$ In addition, previous studies have focused on a few primary predictors of interest (e.g. practice size, practice type, external incentives) rather than capturing a broad scope of characteristics in a single study.

Therefore, we drew a sample from a national database of HCs and built a conceptual model to identify characteristics important for PCMH capability in HCs. We assessed PCMH capability using a validated medical home scale developed for safety net clinics ${ }^{27}$ and measured HC, patient, neighborhood, and regional characteristics by combining different data sources. This study helps HCs and policymakers identify strategies that are most effective for promoting PCMH adoption.

\section{METHODS}

\section{Study Sample and Data Source}

We identified 1014 HCs that were funded by the HRSA Community Health Center (CHC) programs [i.e. Section 330 (e) of the Public Health Service Act] using data from the 2009 Uniform Data System (UDS), a database that tracks information for Section 330 grantees. ${ }^{28}$ Among these, 749 (74\%) completed the 2009 Commonwealth Fund National Survey of Federally Qualified Health Centers, ${ }^{29}$ which generated scores on a scale from 0 to 100 as a measure of PCMH capability. ${ }^{27}$ We then merged these data with data extracted from the 2007-2011 American Community Survey, ${ }^{30} 2007$ HRSA-American Medical Association physician data, ${ }^{31}$ and 2009 state support of PCMH activities data from the National Academy for State Health Policy Medical Home and PatientCentered Care project. We excluded HCs with any missing covariates $(n=43)$, and ultimately included in our final analyses $706 \mathrm{HCs}$ from all 50 states and the District of Columbia, which represented 70\% (706/1014) of HRSA CHC-funded HCs in 2009.

Compared with the $706 \mathrm{HCs}$ included in the analysis, the 308 excluded HCs tended to have fewer patients, more medical visits per physician full-time equivalent (FTE), and a greater number of younger, minority, and homeless patients, and were located in Primary Care Service Areas (PCSAs) with a larger proportion of minority population (Supplemental Table 1).

\section{Measuring Patient-Centered Medical Home (PCMH) Capability}

Our measure of PCMH capability reflects ratings from HC leaders on the presence and effectiveness of organizational structures and clinical processes that are consistent with the PCMH model. It was assessed by executive directors via the 2009 Commonwealth survey and was scored by the Safety Net Medical Home Scale (SNMHS), a validated scale developed in safety net clinics. ${ }^{27,29}$ SNMHS included aspects that were of particular importance to safety net clinics, such as providing timely specialty care for uninsured patients and providing language services for patients with limited or no English proficiency. ${ }^{32}$ The scale generated scores on a scale of 0 (worst) to 100 (best) for six PCMH subscales: access and communication, patient tracking and registry, care management, test and referral tracking, quality improvement, and external coordination (Supplemental Table 2). The overall PCMH capability was measured by the total score, calculated as the mean of the six PCMH subscale scores.

\section{Measuring Health Center, Patient, Neighborhood, and Regional Characteristics}

We built a conceptual model based on previous studies to identify characteristics that are likely to be associated with PCMH capability. Though characteristics were extracted from different data sources, they were all analyzed at the HC level. Table 1 provides a list of the characteristics that we were able to assess, along with the references, the measures used, the expected association with PCMH capability, and the data sources.

Some of the variables we used reflect operating characteristics of HCs, including the presence of an electronic health record, financial performance incentive, and hospital affiliation. While we investigated these factors because we believe that they are important for supporting HCs in becoming medical homes, these characteristics are separate and distinct from the measure of PCMH capability used in the study.

Presence of an EHR (yes or no). Although having an EHR may facilitate PCMH capabilities such as generating lists of patients by diagnosis, it is not necessary for the generation of such lists, which can, for example, be generated from a practice's billing records. In fact, in our study, $67 \%$ of $\mathrm{HCs}$ without an EHR reported that they could accomplish this task "within 24hours".

Financial Performance Incentive (0-10). The financial performance incentive was based on the availability of financial incentives for five targeted activities: achieving high patient satisfaction, achieving a certain clinical care target, participating in quality improvement (QI) activities, managing patients with chronic diseases or complex needs, and using information technology (IT). For each incentive type, the $\mathrm{HC}$ received one point if the incentive was available to the clinic and another point if it was available to the individual provider; thus the scale ranged from 0 to $10(2$ points per type $\times 5$ types). While some of the incentives 
Table 1 Conceptual Model for Characteristics Associated with Patient-Centered Medical Home (PCMH) Capability

\begin{tabular}{|c|c|c|c|c|c|}
\hline Domain & Concept & $\begin{array}{l}\text { Significant } \\
\text { findings in } \\
\text { previous } \\
\text { studies }\end{array}$ & Measure & $\begin{array}{l}\text { Hypothesis: higher } \\
\text { PCMH capability is } \\
\text { associated with ... }\end{array}$ & Data sources \\
\hline \multirow[t]{7}{*}{$\begin{array}{l}\text { Health center } \\
\text { characteristics }\end{array}$} & $\begin{array}{l}\text { Operating margin } \\
\text { Practice size }\end{array}$ & $\begin{array}{l}9-12,14- \\
17,19,20,22,27\end{array}$ & $\begin{array}{l}\% \text { margin }^{\dagger} \\
\text { Annual patient } \\
\text { volume }\end{array}$ & $\begin{array}{l}\text { Higher operating margin } \\
\text { Larger size }\end{array}$ & \multirow[t]{3}{*}{$2009 \mathrm{UDS}^{28}$} \\
\hline & $\begin{array}{l}\text { Medical visits per } \\
\text { physician FTE }\end{array}$ & & $\begin{array}{l}\text { Medical visits per } \\
\text { physician FTE }\end{array}$ & $\begin{array}{l}\text { Fewer medical visits per } \\
\text { physician FTE }\end{array}$ & \\
\hline & Staffing mix & & $\begin{array}{l}\text { Ratio of medical } \\
\text { visits to non- } \\
\text { medical visits }\end{array}$ & $\begin{array}{l}\text { Lower ratio of medical } \\
\text { visits to non-medical visits }\end{array}$ & \\
\hline & HIT & 13,16 & Having an EHR ${ }^{\ddagger}$ & Having an EHR & \multirow{4}{*}{$\begin{array}{l}2009 \text { Commonwealth Fund } \\
\text { National Survey of Federally } \\
\text { Qualified Health Centers }\end{array}$} \\
\hline & Financial incentive & $10,11,16$ & $\begin{array}{l}\text { No. of financial } \\
\text { performance } \\
\text { incentive types }\end{array}$ & $\begin{array}{l}\text { More types of financial } \\
\text { performance incentive }\end{array}$ & \\
\hline & $\begin{array}{l}\text { Relationship with } \\
\text { external }\end{array}$ & 15 & $\begin{array}{l}\text { No. of affiliations } \\
\text { with local hospitals }\end{array}$ & $\begin{array}{l}\text { More types of affiliation } \\
\text { with local hospitals }\end{array}$ & \\
\hline & Location & 13 & Urban/rural location $^{\#}$ & Presence in urban area & \\
\hline \multirow{7}{*}{$\begin{array}{l}\text { Patient } \\
\text { characteristics } \\
\text { (aggregated to each } \\
\text { HC level) }\end{array}$} & Demographic & $19,24-26$ & $\begin{array}{l}\text { Average age of } \\
\text { patients }\end{array}$ & Younger patients & \multirow[t]{7}{*}{$2009 \operatorname{UDS}^{28}$} \\
\hline & & & $\begin{array}{l}\% \text { female patients } \\
\% \text { minority patients }\end{array}$ & $\begin{array}{l}\text { More female patients } \\
\text { Fewer minority patients }\end{array}$ & \\
\hline & Socioeconomic & 25 & $\begin{array}{l}\% \text { patients } \leq 100 \% \\
\text { FPL }\end{array}$ & Fewer patients $\leq 100 \%$ FPL & \\
\hline & & & $\%$ homeless patients & Fewer homeless patients & \\
\hline & Insurance status & $21,24-27$ & $\%$ Medicaid patients & Fewer Medicaid patients & \\
\hline & & & & $\begin{array}{l}\text { Fewer uninsured patients } \\
\text { Fewer managed care }\end{array}$ & \\
\hline & $\begin{array}{l}\text { Chronic disease } \\
\text { burden }\end{array}$ & 26 & $\begin{array}{l}\% \text { medical visits } \\
\text { related to chronic } \\
\text { conditions }\end{array}$ & $\begin{array}{l}\text { Fewer visits related to } \\
\text { chronic disease }\end{array}$ & \\
\hline \multirow[t]{6}{*}{$\begin{array}{l}\text { Neighborhood } \\
\text { characteristics }\end{array}$} & Demographic & 13,18 & $\begin{array}{l}\% \text { minority } \\
\text { population }\end{array}$ & Lower minority rate & \multirow[t]{5}{*}{$\begin{array}{l}\text { 2007-2011 ACS 5-year esti- } \\
\text { mates }^{30}+1\end{array}$} \\
\hline & Socioeconomic & 13,18 & $\begin{array}{l}\% \text { population } \\
\leq 200 \% \mathrm{FPL}\end{array}$ & Lower poverty rate & \\
\hline & & & $\begin{array}{l}\% \text { population } \\
\geq 25 \text { years with } \\
\text { less than high } \\
\text { school education }\end{array}$ & $\begin{array}{l}\text { Lower rate for less than } \\
\text { high school education }\end{array}$ & \\
\hline & & & $\begin{array}{l}\% \text { population } \\
\geq 5 \text { years with } \\
\text { poor spoken } \\
\text { English }\end{array}$ & $\begin{array}{l}\text { Lower rate for poor spoken } \\
\text { English }\end{array}$ & \\
\hline & & & $\begin{array}{l}\% \text { unemployed } \\
\text { population in } \\
\text { civil labor }\end{array}$ & Lower rate for unemployed & \\
\hline & Health system & 13,15 & $\begin{array}{l}\text { PCP per } 100,000 \\
\text { population }\end{array}$ & Higher PCP supply & $\begin{array}{l}2007 \text { HRSA-AMA physician } \\
\text { data }^{31 \S \S}\end{array}$ \\
\hline
\end{tabular}

(continued on next page)

encouraged activities that are core aspects of the PCMH in our scale (e.g. QI), we believe that the presence of financial incentives for those activities is distinct from actually conducting effective activities. Therefore, we examined financial incentive as an independent variable.

Hospital Affiliation (0-6). Hospital affiliation was based on the availability of six types of relationships with local hospitals: referral of patients to specialist/subspecialist care, admitting privileges, receiving referrals from the hospital, serving as a residency training site for the hospital, hospital support of QI activities, and hospital support of IT adoption/ use. The $\mathrm{HC}$ received one point for each available affiliation type, and thus the scale ranged from 0 to 6 . Similar to financial performance incentives, we believe that affiliation with local hospitals is distinct from providing well-coordinated care with external providers, and therefore we examined hospital affiliation as an independent variable.

Results did not differ when financial performance incentive and hospital affiliation were examined individually rather than as summary scales.

\section{Statistical Analysis}

We examined cross-sectional associations between HC, patient, neighborhood and regional characteristics, and PCMH capability using generalized estimating equation (GEE) 
Table 1. (continued)

\begin{tabular}{|c|c|c|c|c|c|}
\hline Domain & Concept & $\begin{array}{l}\text { Significant } \\
\text { findings in } \\
\text { previous } \\
\text { studies }\end{array}$ & Measure & $\begin{array}{l}\text { Hypothesis: higher } \\
\text { PCMH capability is } \\
\text { associated with ... }\end{array}$ & Data sources \\
\hline \multirow[t]{2}{*}{$\begin{array}{l}\text { Regional } \\
\text { characteristics }\end{array}$} & $\begin{array}{l}\text { State-level health } \\
\text { policy }\end{array}$ & & $\begin{array}{l}\text { State support of } \\
\text { PCMH activities in } \\
2009^{q \uparrow}\end{array}$ & \multirow{2}{*}{$\begin{array}{l}\text { HC location in a state with } \\
\text { state-supported PCMH ini- } \\
\text { tiatives and incentive pay- } \\
\text { ment for PCMH activities } \\
\text { HC location in certain } \\
\text { divisions }\end{array}$} & \multirow{2}{*}{$\begin{array}{l}\text { Email communications with } \\
\text { researchers from NASHP } \\
\text { Medical Home and Patient- } \\
\text { Centered Care project } \\
2009 \text { UDS }\end{array}$} \\
\hline & Geographic area & & Census division ${ }^{\# \#}$ & & \\
\hline
\end{tabular}

Abbreviations: FTE full-time equivalent, HIT health information technology, EHR electronic health record, FPL federal poverty line, PCP primary care physician, UDS uniform data system, ACS American Community Survey, HRSA Health Resources and Services Administration, AMA American Medical Association, NASHP National Academy for State Health Policy

* Previous studies may have used different measures to capture the same concept for outcome (e.g. using care management processes for the practice, having a medical home for the patient) or for independent variable (e.g. health IT index as a continuous variable for the practice, racelethnicity, insurance type, and primary language for the patient)

+ Percent margin was calculated as (total revenue - total cost)/total revenue

*We asked, "Do you currently use electronic patient medical records through your health center?", and provided "yes" and "no" options

$\S$ We asked whether the health center and/or individual providers could receive any financial incentives for (a) high patient satisfaction ratings, (b) achieving certain clinical care targets, (c) participation in quality improvement (QI) activities, (d) managing patients with chronic diseases or complex needs, and (e) adoption or use of health IT. For each incentive type, the HC received one point if it was available to the clinic and another point if it was available to the individual provider, and thus the total count ranged from 0 to 10 ( 2 points per type $\times 5$ types)

" We asked whether any of these six types of relationships were available at the HC's largest site: (a) referrals of your patients for specialist or subspecialist care, (b) physician admitting privileges, (c) referrals from the hospital (e.g. from emergency room or from newborn nursery), (d) residency training site for hospital, (e) hospital support of QI activities (i.e. financial and/or collaborative support), and (f) hospital support of IT adoption and use (i.e. financial and/or collaborative support). The HC received one point for each available affiliation type, and thus the total count ranged from 0 to 6 \# We asked, "Where is your sitelyour center's largest site located?", and provided five options: city, suburban, small town, rural and frontier. In the analysis, the options "city" and "suburban" were grouped as the "urban" category and the options "small town", "rural" and "frontier" were grouped as the "rural" category

"Minority patients (population) were Hispanic or non-white patients (population)

** Chronic conditions were defined by HRSA, including diabetes, selected heart diseases, hypertension, asthma, chronic bronchitis, emphysema, human immunodeficiency virus infection, hepatitis $B$, and hepatitis $C$

HT The data were available at ZIP Code Tabulation Area (ZCTA) level and were available from the U.S. Census Bureau website. We mapped each HC site to a ZCTA based on the ZIP Code provided in UDS, aggregated the demographic and socioeconomic characteristics into Primary Care Service Area (PCSA) level for each HC site, and then calculated the average value among all PCSAs that would be served by the HC

tt Poor spoken English meant language spoken at home other than English, and the spoken English level was less than "very well"

S\& The data were available at the PCSA level and were available from the HRSA data warehouse. We mapped each HC site to a PCSA based on the ZIP Code provided in UDS and then calculated the average primary care provider supply among all PCSAs that would be served by the HC

१ศ This measure had three levels: HC location in a state without state-supported PCMH activities in 2009 (states not included in the other two categories), HC location in a state with significant state-supported PCMH activities but without PCMH payment in 2009 (MA, ME, MN, NY), and HC location in a state with state-supported PCMH initiatives and incentive payments for PCMH activities in 2009 (CO, IL, NH, NM, NC, OK, PA, RI, VT, WA). In the analysis, the first level-HC location in a state without state-supported PCMH activities in 2009-is the reference group. According to National Academy for State Health Policy (NASHP) instructions, medical home activity must meet the following: (1) program implementation (or major expansion or improvement) in 2006 or later; (2) Medicaid or Children's Health Insurance Program (CHIP) participation (not necessarily leadership); (3) explicit intention to advance medical homes for Medicaid or CHIP participants; and (4) evidence of commitment, such as working groups, legislation, executive orders, or dedicated staff. Payment for medical home activity was defined as having "implemented new payments or revised existing ones to primary care providers so they may function as patient-centered medical home", including the following: per-member per-month care management fee, pay-for-performance fee, support for practice training, and payment to support upfront costs. We created this variable based on email communications with researchers from NASHP. Information for the most recent status of Medicaid/CHIP-supported medical home activity in each state is available from the online interactive map (http://nashp.org/medical-home-patient-centered-care-maps/index.html)

\# The 50 states and the District of Columbia were classified into nine census divisions: New England (CT, MA, ME, NH, RI, VT), Middle Atlantic (NJ, NY, PA), East North Central (IL, IN, MI, OH, WI), West North Central (IA, KS, MN, MO, ND, NE, SD), South Atlantic (DC, DE, FL, GA, MD, NC, SC, $V A, W V$ ), East South Central (AL, KY, MS, TN), West South Central (AR, LA, OK, TX), Mountain (AZ, CO, ID, MT, NM, NV, UT, WY) and Pacific (AK, $C A, H I, O R, W A)$

models to account for the clustering effect of clinics within states. We modeled each outcome with each covariate in bivariate analyses and excluded those that had no significant relationship with any outcomes in multivariate analyses. We used a $p$-value less than 0.2 as the selection criterion $^{33}$ and adjusted it to $0.029(=0.2 / 7)$ to account for multiple hypothesis testing. ${ }^{34}$ After the selection of variables, we fitted multivariate models for each of the seven outcomes. Results did not differ when all covariates were included in the models.

Because EHR adoption in HCs has increased substantially since $2009,{ }^{35,36}$ we performed subgroup analyses among 310
HCs with an EHR to examine whether the characteristics associated with PCMH capability differed for this group.

We interpreted the results as the point change in PCMH scores given one unit increase for the continuous variable (e.g. one additional type of financial performance incentive) or given $\mathrm{HCs}$ in group A versus group B for the categorical variable (e.g. having an EHR vs. no EHR). For reference, HC A would have a total PCMH score one point higher than $\mathrm{HC}$ B if $\mathrm{HC}$ A provided regular/well visits during weekends while HC B did not. Previous studies have found that a onepoint higher total PCMH score was associated with a $\$ 0.23$ 
Table 2 Distribution of Health Center, Patient, Neighborhood and Regional Characteristics, and Patient-Centered Medical Home Capability $(n=706)$

\begin{tabular}{|c|c|c|c|}
\hline & & Mean (SD) & Median (IQR) \\
\hline \multirow[t]{8}{*}{ Health center characteristics } & Percent margin & $2.5(10.0)$ & $2.5(-2.8$ to 7.4$)$ \\
\hline & Annual patient volume $(000 \mathrm{~s})$ & $19.1(19.8)$ & $13.2(7.2-23.0)$ \\
\hline & Medical visits per physician FTE (000s) & $7.2(4.7)$ & $6.2(5.0-7.9)$ \\
\hline & Ratio of medical visits to non-medical visits & $1.1(2.0)$ & $0.8(0.5-1.3)$ \\
\hline & $\begin{array}{l}\text { No. of financial performance incentive types } \\
\text { (maximum possible }=10 \text { ) }\end{array}$ & $1.7(2.3)$ & $1(0-3)$ \\
\hline & No. of hospital affiliation types (maximum & $2.9(1.3)$ & $3(2-4)$ \\
\hline & Having an EHR, $n(\%)$ & $310(43.9)$ & \\
\hline & Urban location, $n(\%)$ & $367(52.0)$ & \\
\hline \multirow[t]{9}{*}{ Patient characteristics } & Patient age, years & $32.9(5.7)$ & $32.6(28.8-36.7)$ \\
\hline & Percent female patients & $58.7(5.3)$ & $58.6(55.8-61.7)$ \\
\hline & Percent minority patients & $46.0(32.4)$ & $48.0(13.4-73.2)$ \\
\hline & Percent patients $\leq 100 \%$ FPL & $66.9(17.3)$ & $69.4(57.5-79.2)$ \\
\hline & Percent homeless patients & $2.7(6.8)$ & $0.4(0-2.7)$ \\
\hline & Percent Medicaid-covered patients & $32.6(14.5)$ & $30.9(21.0-43.3)$ \\
\hline & Percent uninsured patients & $37.9(17.4)$ & $36.0(24.8-49.1)$ \\
\hline & Percent managed care patients & $17.6(20.8)$ & $9.2(0-32.5)$ \\
\hline & Percent medical visits related to chronic diseases & $20.3(10.2)$ & $17.9(13.7-24.3)$ \\
\hline \multirow[t]{6}{*}{ Neighborhood characteristics } & Percent minority population & $37.1(25.6)$ & $33.2(14.3-54.9)$ \\
\hline & Percent population $\leq 200 \%$ FPL & $39.2(9.8)$ & $38.4(32.5-44.9)$ \\
\hline & $\begin{array}{l}\text { Percent population less than high school } \\
\text { education }\end{array}$ & $17.3(7.5)$ & $15.5(12.1-22)$ \\
\hline & Percent population with poor spoken English & $8.1(9.2)$ & $4.2(1.7-10.5)$ \\
\hline & Percent unemployed population & $9.5(3.1)$ & $9.1(7.5-11.1)$ \\
\hline & Primary care physician per 100,000 population & $79.4(44.2)$ & $72.5(54.6-94.0)$ \\
\hline \multirow[t]{17}{*}{ Regional characteristics } & State support of PCMH activities in $2009, n(\%)$ & & \\
\hline & $\begin{array}{l}\text { HC location in a state without state-supported } \\
\text { PCMH activities }\end{array}$ & $497(70.4)$ & \\
\hline & HC location in a state with state-supported & 77 (10.9) & \\
\hline & PCMH activities but without PCMH payment & & \\
\hline & HC location in a state with state-supported & $132(18.7)$ & \\
\hline & PCMH initiatives and incentive payment to & & \\
\hline & PCMH activities & & \\
\hline & US census division, $n(\%)$ & & \\
\hline & New England & $61(8.6)$ & \\
\hline & Middle Atlantic & $61(8.6)$ & \\
\hline & East North Central & 89 (12.6) & \\
\hline & West North Central & $59(8.4)$ & \\
\hline & South Atlantic & $130(18.4)$ & \\
\hline & East South Central & $54(7.7)$ & \\
\hline & West South Central & $69(9.8)$ & \\
\hline & Mountain & $54(7.7)$ & \\
\hline & Pacific & $129(18.3)$ & \\
\hline \multirow[t]{7}{*}{ PCMH capability } & $\begin{array}{l}\text { Total PCMH score, } 0-100 \text { (worst to best) } \\
\text { PCMH subscales } 0-100 \text { (worst to best) }\end{array}$ & $61.8(12.0)$ & $61.7(53.2-70.5)$ \\
\hline & $\begin{array}{l}\text { PCMH subscales, 0-100 (worst to best) } \\
\text { Access and communication with patients }\end{array}$ & $680(135)$ & $688(583-792)$ \\
\hline & Patient tracking and registry & $64.7(24.7)$ & $66.7(46.7-86.7)$ \\
\hline & Care management & $49.6(18.6)$ & $50.0(35.0-63.2)$ \\
\hline & Test and referral tracking & $70.5(23.5)$ & $75.0(54.2-91.7)$ \\
\hline & Quality improvement & $59.3(15.1)$ & $60.0(50.0-70.0)$ \\
\hline & External coordination & $59.1(17.9)$ & $59.1(47.9-70.8)$ \\
\hline
\end{tabular}

Abbreviations: SD standard deviation, IQR interquartile range, FTE full-time equivalent, EHR electronic health record, FPL federal poverty level, PCMH patient-centered medical home

$(0.5 \%)$ higher operating cost per patient per month ${ }^{37}$ and a $0.07 \%$ higher rate for diabetes control. ${ }^{38}$

All statistical tests were two-sided. Analysis was performed with SAS software version 9.3(SAS Institute Inc., Cary, NC). The University of Chicago Institutional Review Board designated this study as exempt from review.

\section{RESULTS}

\section{Study Sample}

On average, the $706 \mathrm{HCs}$ included in the analysis served 19,085 patients annually, with $46.0 \%$ minority patients, $32.6 \%$ Medicaid patients, and 37.9\% uninsured patients 
Table 3 Bivariate Associations Between Characteristics and PCMH Capability $(n=706)$

\begin{tabular}{|c|c|c|c|c|c|c|c|}
\hline \multirow[t]{2}{*}{ Characteristics } & \multirow{2}{*}{$\begin{array}{l}\text { Total } \\
\text { PCMH } \\
\text { score }\end{array}$} & \multicolumn{6}{|l|}{ PCMH subscales } \\
\hline & & $\begin{array}{l}\text { Access and } \\
\text { communication }\end{array}$ & $\begin{array}{l}\text { Patient } \\
\text { tracking } \\
\text { and } \\
\text { registry }\end{array}$ & $\begin{array}{l}\text { Care } \\
\text { management }\end{array}$ & $\begin{array}{l}\text { Test and } \\
\text { referral } \\
\text { tracking }\end{array}$ & $\begin{array}{l}\text { Quality } \\
\text { improvement }\end{array}$ & $\begin{array}{l}\text { External } \\
\text { coordination }\end{array}$ \\
\hline \multicolumn{8}{|l|}{ Health center characteristics } \\
\hline$\%$ margin & 0.07 & 0.04 & 0.008 & 0.09 & $0.17^{*}$ & 0.11 & -0.03 \\
\hline Annual patient volume (000s) & $0.08^{* *}$ & $0.09^{* * *}$ & 0.02 & $0.12^{* *}$ & 0.05 & $0.17^{* * *}$ & $0.02^{* *}$ \\
\hline $\begin{array}{l}\text { Medical visits per physician } \\
\text { FTE }(000 \mathrm{~s})^{\dagger}\end{array}$ & 0.05 & 0.04 & 0.04 & 0.04 & 0.16 & 0.01 & -0.12 \\
\hline $\begin{array}{l}\text { Ratio of medical to non- } \\
\text { medical visits }\end{array}$ & -0.06 & -0.12 & -0.19 & -0.29 & 0.20 & $-0.49^{* *}$ & $0.80^{* *}$ \\
\hline $\begin{array}{l}\text { No. financial performance } \\
\text { incentive types (maximum } \\
\text { possible }=10 \text { ) }\end{array}$ & $1.18^{* * * *}$ & $0.95^{* * *}$ & $1.71^{* * *}$ & $1.48^{* * *}$ & $1.14^{* *}$ & $1.27^{* * * *}$ & 0.67 \\
\hline $\begin{array}{l}\text { No. hospital affiliation types } \\
\text { (maximum possible }=6 \text { ) }\end{array}$ & $2.13^{* * *}$ & $1.00^{* *}$ & $1.68^{*}$ & $2.53^{* * *}$ & $1.65^{* *}$ & $1.89^{* * *}$ & $4.14^{* * *}$ \\
\hline Having an EHR & $12.4^{* * *}$ & $2.71^{* * *}$ & $27.6^{* * *}$ & $20.1^{* * *}$ & $13.8^{* * *}$ & $3.77^{* * *}$ & $4.40^{* *}$ \\
\hline Urban location & 0.99 & $2.45^{* *}$ & 2.33 & 2.37 & -1.50 & 2.10 & -0.52 \\
\hline \multicolumn{8}{|l|}{ Patient characteristics } \\
\hline Average patient age & -0.07 & $-0.30^{* *}$ & -0.07 & -0.04 & 0.23 & $-0.38^{* * *}$ & 0.10 \\
\hline$\%$ female patients ${ }^{\dagger}$ & -0.07 & -0.03 & -0.09 & -0.08 & 0.06 & -0.04 & -0.10 \\
\hline$\%$ minority patients & -0.01 & -0.005 & $0.07^{*}$ & 0.003 & -0.05 & 0.005 & $-0.06^{*}$ \\
\hline$\%$ patients $\leq 100 \% \mathrm{FPL}^{\dagger}$ & -0.03 & -0.01 & 0.03 & -0.04 & -0.10 & 0.02 & -0.05 \\
\hline$\%$ homeless patients & 0.10 & 0.15 & $0.27^{* *}$ & 0.18 & 0.03 & 0.09 & -0.12 \\
\hline$\%$ Medicaid patients & 0.03 & 0.10 * & 0.03 & 0.06 & -0.10 & $0.17^{* * *}$ & -0.03 \\
\hline$\%$ uninsured patients & $-0.06^{*}$ & -0.04 & -0.01 & -0.07 & 0.008 * & $-0.10^{* * *}$ & $-0.11^{* *}$ \\
\hline$\%$ managed care & -0.01 & $0.06^{*} *$ & -0.03 & 0.02 & -0.12 * & 0.04 & 0.003 \\
\hline $\begin{array}{l}\% \text { visits related to chronic } \\
\text { conditions }\end{array}$ & $-0.08^{*}$ & $-0.11^{*}$ & -0.10 & $-0.16^{*}$ & 0.08 & $-0.16^{* *}$ & -0.07 \\
\hline \multicolumn{8}{|l|}{ Neighborhood characteristics } \\
\hline$\%$ minority population & -0.004 & $0.01 *$ & $0.08^{*}$ & 0.01 & -0.04 & 0.006 & $-0.09^{* *}$ \\
\hline$\%$ population $\leq 200 \% \mathrm{FPL}^{\dagger}$ & -0.05 & $-0.14^{*}$ & -0.06 & -0.07 & -0.007 & -0.09 & -0.06 \\
\hline $\begin{array}{l}\% \text { population less than high } \\
\text { school education }\end{array}$ & -0.02 & -0.05 & -0.01 & -0.10 & 0.19 & -0.08 & -0.11 \\
\hline $\begin{array}{l}\% \text { population with poor } \\
\text { English }^{\dagger}\end{array}$ & 0.04 & 0.09 & 0.07 & 0.08 & 0.008 & 0.07 & -0.08 \\
\hline$\%$ unemployed population $^{\dagger}$ & -0.06 & -0.02 & 0.10 & 0.08 & -0.27 & -0.05 & -0.32 \\
\hline PCP per 100,000 population & 0.02 & $0.03^{* * *}$ & 0.04 & $0.04^{*}$ & -0.01 & $0.03^{*}$ & 0.007 \\
\hline \multicolumn{8}{|c|}{ Regional characteristics } \\
\hline \multicolumn{8}{|c|}{ State support of PCMH activities in 2009} \\
\hline $\begin{array}{l}\text { HC location in a state with } \\
\text { state-supported PCMH } \\
\text { initiatives and PCMH } \\
\text { payment }\end{array}$ & $3.86^{*}$ & 2.49 & 5.99 & 4.57 & 0.32 & $3.96^{*}$ & 2.71 \\
\hline $\begin{array}{l}\text { HC location in a state with } \\
\text { state-supported PCMH } \\
\text { activities but without } \\
\text { PCMH payment }\end{array}$ & $5.48^{* * *}$ & $6.77^{* * *}$ & 3.17 & $5.27^{*}$ & 2.42 & $5.05^{* *}$ & $12.3^{* * *}$ \\
\hline \multicolumn{8}{|l|}{$\begin{array}{l}\text { PCMH payment } \\
\text { US census division }\end{array}$} \\
\hline New England & $7.21^{* * *}$ & $8.99^{* * * *}$ & $9.19^{*}$ & $6.67^{* *}$ & 3.23 & $4.64^{*} *$ & $10.6^{* *}$ \\
\hline Middle Atlantic & 0.19 & $7.88^{* * *}$ & -4.20 & -2.61 & -3.51 & $5.80^{*}$ & -0.20 \\
\hline East North Central & -1.34 & 3.27 & -4.70 & -4.51 & -6.22 & $3.99^{*}$ & 0.41 \\
\hline West North Central & -0.04 & 1.00 & -2.64 & -1.82 & -5.53 & $4.48^{* *}$ & $5.89^{*}$ \\
\hline South Atlantic & 0.66 & 1.64 & 5.62 & -2.24 & 1.99 & 0.76 & -3.70 \\
\hline West South Central & -1.04 & 0.65 & 1.08 & $-3.45^{* * *}$ & 0.19 & -0.09 & $-7.77^{* *}$ \\
\hline Mountain & -1.24 & 2.47 & -0.20 & -3.72 & -6.08 & 0.51 & -1.44 \\
\hline Pacific & -0.95 & 2.90 & 4.10 & 3.49 & -3.92 & -0.02 & $-10.1^{* * *}$ \\
\hline
\end{tabular}

Abbreviations: PCMH patient-centered medical home, FTE full-time equivalent, EHR electronic health record, FPL federal poverty level, PCP primary care physician, HC health center

${ }^{*} p<0.05,{ }^{* *} p<0.01,{ }^{* * *} p<0.001$

Variables removed in the multivariate models

* Reference group was HC location in a state without state-supported PCMH activities in 2009

$\S$ Reference group was East South Central division

(Table 2). Less than half of the HCs (43.9\%) used an EHR. HCs received an average of 1.7 (standard deviation, $\mathrm{SD}=2.3$ ) types of financial performance incentives (maximum possible $=10)$ and had an average of $2.9(\mathrm{SD}=1.3)$ types of hospital 
Table 4 Multivariate Associations between Characteristics and PCMH Capability $(n=706)$

\begin{tabular}{|c|c|c|c|c|c|c|c|}
\hline \multirow[t]{2}{*}{ Characteristics } & \multirow{2}{*}{$\begin{array}{l}\text { Total } \\
\text { PCMH } \\
\text { score }\end{array}$} & \multicolumn{6}{|l|}{ PCMH subscales } \\
\hline & & $\begin{array}{l}\text { Access and } \\
\text { communication }\end{array}$ & $\begin{array}{l}\text { Patient } \\
\text { tracking } \\
\text { and } \\
\text { registry }\end{array}$ & $\begin{array}{l}\text { Care } \\
\text { management }\end{array}$ & $\begin{array}{l}\text { Test and } \\
\text { referral } \\
\text { tracking }\end{array}$ & $\begin{array}{l}\text { Quality } \\
\text { improvement }\end{array}$ & $\begin{array}{l}\text { External } \\
\text { coordination }\end{array}$ \\
\hline \multicolumn{8}{|l|}{ Health center characteristics } \\
\hline$\%$ margin & $0.09^{* *}$ & 0.05 & 0.02 & $0.10^{*}$ & $0.20_{* *}^{* *}$ & $0.13^{*}$ & -0.007 \\
\hline Annual patient volume $(000 \mathrm{~s})$ & $0.04^{*}$ & $0.05^{*}$ & -0.05 & $0.06^{*}$ & $0.09^{*}$ & $0.13^{* * *}$ & -0.03 \\
\hline $\begin{array}{l}\text { Ratio of medical visits to non- } \\
\text { medical visits }\end{array}$ & -0.18 & -0.07 & -0.38 & -0.52 & -0.06 & $-0.61^{* *}$ & $0.74^{* *}$ \\
\hline $\begin{array}{l}\text { No. of financial performance } \\
\text { incentive types (maximum } \\
\text { possible }=10 \text { ) }\end{array}$ & $0.66^{* *}$ & $0.60^{*}$ & $0.85^{*}$ & $0.55^{*}$ & $0.98^{* *}$ & $0.83^{* *}$ & 0.24 \\
\hline $\begin{array}{l}\text { No. of hospital affiliation types } \\
\text { (maximum possible }=6 \text { ) }\end{array}$ & $1.62^{* * *}$ & 0.23 & 0.86 & $1.78^{* * *}$ & $1.59^{*}$ & 0.99 & $4.14^{* * *}$ \\
\hline Having an EHR & $11.7^{* * *}$ & 1.78 & $26.7^{* * *}$ & $20.1^{* * *}$ & $12.7^{* * *}$ & $3.53^{* *}$ & $4.01^{* * *}$ \\
\hline Urban location & 0.11 & 0.79 & -0.75 & 0.05 & 0.99 & -0.85 & 0.14 \\
\hline \multicolumn{8}{|l|}{ Patient characteristics } \\
\hline Average patient age & -0.07 & $-0.40^{* *}$ & -0.007 & 0.17 & -0.04 & -0.20 & -0.03 \\
\hline$\%$ minority patients & $-0.04 *$ & $-0.08^{* *}$ & 0.05 & -0.02 & -0.10 & $-0.05^{*}$ & -0.04 \\
\hline$\%$ homeless patients & 0.06 & 0.13 & 0.22 * & 0.12 & -0.02 & 0.07 & -0.09 \\
\hline$\%$ Medicaid patients & -0.03 & -0.04 & -0.006 & 0.02 & -0.02 & 0.05 & -0.16 \\
\hline$\%$ uninsured patients & -0.05 & -0.01 & -0.09 & -0.03 & 0.03 & -0.04 & -0.10 \\
\hline$\%$ managed care & -0.04 & -0.006 & -0.09 & 0.007 & -0.14 * & -0.03 & 0.04 \\
\hline$\%$ visits related to chronic conditions & -0.02 & -0.02 & -0.11 & -0.12 & 0.11 & -0.03 & 0.05 \\
\hline \multicolumn{8}{|l|}{ Neighborhood characteristics } \\
\hline$\%$ minority population & 0.04 & 0.06 & 0.07 & 0.04 & 0.06 & 0.05 & -0.05 \\
\hline PCP per 100,000 population & 0.005 & 0.02 & 0.008 & 0.01 & -0.02 & 0.02 & -0.008 \\
\hline \multicolumn{8}{|l|}{ Regional characteristics } \\
\hline \multicolumn{8}{|c|}{ State support of PCMH activities in $2009^{\dagger}$} \\
\hline $\begin{array}{l}\text { HC location in a state with state- } \\
\text { supported PCMH initiatives and } \\
\text { PCMH payment }\end{array}$ & 1.19 & 0.36 & 3.06 & 1.84 & -3.19 & 2.36 & 1.06 \\
\hline $\begin{array}{l}\text { HC location in a state with state- } \\
\text { supported PCMH activities but } \\
\text { without PCMH payment }\end{array}$ & 0.38 & 2.20 & -1.38 & -2.05 & -1.15 & 1.91 & 3.97 \\
\hline \multicolumn{8}{|l|}{ US census division } \\
\hline New England & 0.54 & $5.39^{* *}$ & -1.32 & -3.66 & 2.26 & -1.31 & 2.44 \\
\hline Middle Atlantic & -2.32 & 3.54 & $-7.44^{*}$ & $-7.01^{* *}$ & 1.35 & -1.01 & -1.78 \\
\hline East North Central & -2.35 & 1.10 & -5.35 & $-6.71 *$ & -3.42 & 0.75 & -0.77 \\
\hline West North Central & -0.73 & -1.24 & -3.09 & -2.38 & $-4.91^{*}$ & 2.34 & $5.72^{* *}$ \\
\hline South Atlantic & -1.87 & 1.56 & -2.16 & $-6.88^{* * *}$ & 0.93 & 0.47 & -4.62 \\
\hline West South Central & -1.86 & 0.57 & $-4.20^{* *}$ & $-3.82^{*}$ & -0.50 & 0.65 & $-6.74^{* *}$ \\
\hline Mountain & $-4.26^{* * *}$ & 0.61 & $-5.89^{* *}$ & $-8.233^{* * *}$ & $-6.81 *$ & -2.65 & -2.06 \\
\hline Pacific & $-3.67^{* * *}$ & 0.49 & $-4.03^{* *}$ & $-6.14^{* * *}$ & -1.58 & $-3.86^{* *}$ & $-8.47^{* * *}$ \\
\hline Marginal R-squared ${ }^{\S}$ & 0.36 & 0.10 & 0.34 & 0.35 & 0.14 & 0.14 & 0.27 \\
\hline
\end{tabular}

Abbreviations: $P C M H$ patient-centered medical home, EHR electronic health record, PCP primary care physician, HC health center ${ }^{*} p<0.05,{ }^{* *} p<0.01,{ }^{* * *} p<0.001$

Reference group was HC location in a state without state-supported PCMH activities in 2009

* Reference group was East South Central division

$\S$ Marginal R-squared (range 0 to 1$)^{39}$ indicates how much of the variance in outcomes could be explained by the covariate set. For example, all the characteristics listed in the left column can explain $36 \%$ of the variance in total PCMH score within the sample

affiliations (maximum possible $=6$ ). Only $29.6 \%$ of the $\mathrm{HCs}$ were from states with state-supported PCMH activities in 2009.

The mean of the total PCMH score was $61.8(\mathrm{SD}=12.0)$. Among PCMH subscales, care management had the lowest score $($ mean $=49.6, \mathrm{SD}=18.6)$ and test and referral tracking had the highest score $($ mean $=70.5, \mathrm{SD}=23.5)$.

\section{Bivariate Associations Between Characteristics and PCMH Capability}

In bivariate analyses (Table 3), having an EHR was associated with higher total PCMH score and higher scores for all PCMH subscales. In addition to having an EHR, other characteristics associated with high $\mathrm{PCMH}$ capability included more types of financial 
Table 5 Multivariate Associations Between Characteristics and PCMH Capability Among Health Centers with an EHR $(n=310)^{\dagger}$

\begin{tabular}{|c|c|c|c|c|c|c|c|}
\hline \multirow[t]{2}{*}{ Characteristics } & \multirow{2}{*}{$\begin{array}{l}\text { Total } \\
\text { PCMH } \\
\text { score }\end{array}$} & \multicolumn{6}{|l|}{ PCMH subscales } \\
\hline & & $\begin{array}{l}\text { Access and } \\
\text { communication }\end{array}$ & $\begin{array}{l}\text { Patient } \\
\text { tracking } \\
\text { and registry }\end{array}$ & $\begin{array}{l}\text { Care } \\
\text { management }\end{array}$ & $\begin{array}{l}\text { Test and } \\
\text { referral } \\
\text { tracking }\end{array}$ & $\begin{array}{l}\text { Quality } \\
\text { improvement }\end{array}$ & $\begin{array}{l}\text { External } \\
\text { coordination }\end{array}$ \\
\hline \multicolumn{8}{|l|}{ Health center characteristics } \\
\hline$\%$ margin & $0.12 *$ & -0.04 & 0.15 & 0.13 & $0.34^{* *}$ & 0.06 & -0.04 \\
\hline $\begin{array}{l}\text { Annual patient volume } \\
(000 \mathrm{~s})\end{array}$ & 0.02 & 0.03 & -0.08 & $0.15^{* *}$ & -0.03 & $0.13^{* *}$ & -0.10 \\
\hline $\begin{array}{l}\text { Ratio of medical visits to } \\
\text { non-medical visits }\end{array}$ & -0.19 & $-0.32^{*}$ & -0.34 & -0.33 & -0.11 & $-0.63^{* *}$ & $0.53^{* * *}$ \\
\hline $\begin{array}{l}\text { No. financial } \\
\text { performance incentive } \\
\text { types (maximum } \\
\text { possible }=10 \text { ) }\end{array}$ & $0.67^{* *}$ & $1.00^{* * *}$ & $1.12^{*}$ & 0.001 & 0.40 & $0.91^{*}$ & 0.45 \\
\hline $\begin{array}{l}\text { No. hospital affiliation } \\
\text { types (maximum } \\
\text { possible=6) }\end{array}$ & $1.35^{* * *}$ & 0.12 & -0.48 & 1.09 & $1.73^{*}$ & 1.27 & $4.64^{* * *}$ \\
\hline Urban location & 1.66 & 2.83 & 3.55 & 0.35 & 3.23 & 1.44 & -3.53 \\
\hline \multicolumn{8}{|l|}{ Patient characteristics } \\
\hline Average patient age & 0.17 & 0.04 & 0.19 & 0.42 & 0.12 & 0.07 & -0.02 \\
\hline$\%$ Medicaid patients & 0.02 & 0.01 & 0.18 & -0.001 & -0.04 & 0.06 & -0.13 \\
\hline$\%$ managed care & -0.02 & -0.03 & $-0.15^{*}$ & 0.05 & -0.10 & 0.009 & 0.07 \\
\hline $\begin{array}{l}\% \text { visits related to } \\
\text { chronic conditions }\end{array}$ & $-0.13 *$ & -0.09 & $-0.25^{*}$ & $-0.28^{* *}$ & 0.07 & -0.09 & 0.06 \\
\hline \multicolumn{8}{|l|}{ Neighborhood characteristics } \\
\hline$\%$ minority population & -0.01 & 0.0001 & 0.11 & 0.04 & -0.06 & 0.04 & $-0.16^{* *}$ \\
\hline $\begin{array}{l}\% \text { population } \leq 200 \% \\
\text { FPL }\end{array}$ & 0.07 & -0.12 & 0.11 & 0.03 & 0.003 & 0.01 & $0.30^{* *}$ \\
\hline $\begin{array}{l}\text { \% population with poor } \\
\text { spoken English }\end{array}$ & 0.01 & 0.11 & -0.34 & -0.03 & 0.24 & 0.05 & -0.03 \\
\hline $\begin{array}{l}\text { PCP per } 100,000 \\
\text { population }\end{array}$ & 0.0001 & $0.04^{*}$ & 0.009 & -0.01 & -0.03 & -0.01 & 0.008 \\
\hline \multicolumn{8}{|c|}{$\begin{array}{l}\text { Regional characteristics } \\
\text { State sunnort of PCHH activitios in } 2009^{*}\end{array}$} \\
\hline $\begin{array}{c}\text { State support of PCMH ac } \\
\text { HC location in a state }\end{array}$ & ivities in 2 & & & & & & \\
\hline $\begin{array}{l}\text { HC location in a state } \\
\text { with state-supported } \\
\text { PCMH initiatives } \\
\text { and PCMH payment }\end{array}$ & $2.84^{*}$ & 1.18 & $4.54^{*}$ & 3.75 & 1.83 & 2.87 & 2.06 \\
\hline $\begin{array}{l}\text { HC location in a state } \\
\text { with state-supported } \\
\text { PCMH activities but } \\
\text { without PCMH } \\
\text { payment }\end{array}$ & 0.99 & -1.80 & 5.99 & 0.71 & 0.06 & 2.51 & -1.30 \\
\hline \multicolumn{8}{|l|}{$\begin{array}{l}\text { payment } \\
\text { US census division }\end{array}$} \\
\hline New England & 1.54 & 2.56 & -4.71 & -3.29 & -1.19 & 1.57 & $17.4^{* * *}$ \\
\hline Middle Atlantic & 0.78 & 4.28 & -11.7 & 1.97 & 0.75 & 2.72 & $11.2^{* * * *}$ \\
\hline East North Central & -0.21 & 2.01 & -9.81 & -3.09 & -2.67 & 4.91 & $9.33^{* *}$ \\
\hline West North Central & $3.70^{*}$ & -0.02 & $-7.59^{* *}$ & 4.10 & 5.19 & 1.98 & $19.7^{* * *}$ \\
\hline South Atlantic & 1.17 & 2.29 & -3.03 & -2.03 & 3.30 & 3.01 & 3.76 \\
\hline West South Central & -0.09 & 2.88 & -6.41 & 1.60 & -2.52 & 1.47 & -0.54 \\
\hline Mountain & $-3.51^{*}$ & -1.19 & $-8.10^{*}$ & -3.04 & -6.98 & -4.76 & 6.16 \\
\hline Pacific & -0.95 & -0.18 & -3.93 & 0.35 & -1.86 & 1.33 & 0.67 \\
\hline Marginal R-squared & 0.16 & 0.15 & 0.08 & 0.12 & 0.07 & 0.18 & 0.28 \\
\hline
\end{tabular}

Abbreviations: PCMH patient-centered medical home, EHR electronic health record, FTE full-time equivalent, FPL federal poverty level, PCP primary care physician, HC health center, PCSA primary care service area

${ }^{*} p<0.05,{ }^{* *} p<0.01,{ }^{* * *} p<0.001$

In subgroup analyses, as in the main analyses, we first conducted bivariate models to select variables. The following variables were removed from the multivariate models due to non-significant findings in bivariate analyses after adjusting for multiple hypothesis testing: medical visits per physician FTE, \% female patients, \% minority patients, \% patients $\leq 100 \% \mathrm{FPL}$ \% \% homeless patients, \% uninsured patients, PCSA-level \% population less than high school education, and \% unemployed population

* Reference group was HC location in a state without state-supported PCMH activities in 2009

$\S$ Reference group was East South Central

" Marginal R-squared (range 0-1) ${ }^{39}$ indicates how much of the variance in outcomes could be explained by the covariate set. For example, all the characteristics listed in the left column can explain $16 \%$ of the variance in total PCMH score within the subgroup sample (i.e. HCs with an EHR)

performance incentives, more types of affiliations with local hospitals, location in certain US census divisions, and $\mathrm{HC}$ location in a state with state-supported PCMH activities in 2009 . 


\section{Multivariate Associations Between Characteristics and PCMH Capability}

In multivariate analysis (Table 4), the presence of an EHR was the strongest correlate with high PCMH capability among all of the examined characteristics. Having an EHR was associated with an 11.7-point (95\% confidence interval, CI 10.213.3) higher total PCMH score, with a particularly strong association with patient tracking and registry $(26.7,95 \% \mathrm{CI}$ 23.6-29.8), care management (20.1, 95\% CI 17.5-22.7), and test and referral tracking $(12.7,95 \%$ CI 9.1-16.3).

Having one additional type of financial performance incentive (maximum possible $=10$ ) was associated with a 0.7 -point (95\% CI 0.2-1.1) higher total PCMH score and with higher scores in all PCMH subscales except external coordination.

Having one additional type of hospital affiliation (maximum possible $=6)$ was associated with a 1.6-point $(95 \% \mathrm{CI}$ 1.1-2.1) higher total PCMH score and with higher scores in the subscales care management, test and referral tracking, and external coordination.

Total PCMH score and subscales varied across US census divisions. For example, after controlling for other characteristics, HCs in the Mountain division had a 4.3-point $(95 \%$ CI 2.0-6.5) lower total PCMH score than HCs in the East South Central division.

Other characteristics, such as higher percent margin, larger annual patient volume, and fewer minority patients served by the $\mathrm{HC}$, were also associated with higher PCMH scores.

\section{Subgroup Analyses Among Health Centers with an Electronic Health Record}

In subgroup analyses for $310 \mathrm{HCs}$ with an EHR (Table 5), we observed positive effects of more types of financial performance incentives and more types of hospital affiliations, similar to those in the main analyses among the overall sample. Compared with $\mathrm{HC}$ location in a state without state-supported PCMH activities in 2009, HC location in a state with statesupported PCMH initiatives and PCMH payments (from multi-payer, Medicaid, or Children's Health Insurance Program) had a 2.8-point (95\% CI 0.2-5.5) higher total PCMH score. PCMH scores still varied across census divisions.

\section{DISCUSSION}

We found that several factors were independently associated with PCMH capability in health centers on a national basis, including the presence of an EHR, financial incentives, and hospital affiliations. Each of these factors was correlated with total PCMH score and more than one PCMH subscale. In bivariate analyses, state-supported PCMH initiatives and PCMH payments were also associated. The same general pattern of results was seen when we limited analyses to HCs with EHRs. While a one-point change in PCMH score had a relatively small effect on operating cost and clinical quality, ${ }^{37,38}$ variables with large effect size per unit, those with large room for change, and aggregation of variables may have clinically significant effects on cost and patient outcomes.

While our cross-sectional analysis cannot prove a causal relationship, our finding of a strong correlation between the presence of an EHR and high PCMH capability in HCs suggests that HRSA support for EHR adoption in HCs may have yielded important improvements in PCMH capability. Not surprisingly, the effect of EHR adoption was considerable for the subscale patient tracking and registry and care management. It is worth noting that while EHR was important to the development of PCMH capability, and may enable some PCMH features, it was not essential. ${ }^{40}$ Our PCMH scale did not require an EHR for clinics to obtain a high PCMH score. In our study, $21 \%$ of clinics in the top quartile of total PCMH score did not have an EHR.

Providing more types of financial performance incentives to clinics and providers was associated with higher PCMH capability in HCs. This finding is consistent with results of previous studies in physician organizations, ${ }^{10,11,16}$ yet novel in its specific focus on HCs nationwide. We asked HCs whether the clinic or individual providers could receive financial incentives for achieving goals such as high patient satisfaction and certain clinical care targets. These incentive types feature prominently in major payment reforms such as pay-for-performance. Our findings may suggest that when providers are offered these types of financial incentives, they may implement activities that cause clinics to function more like a PCMH.

Having more types of affiliations with local hospitals was also associated with higher PCMH capability in HCs. This finding is consistent with that of a previous study among family medicine practices in the state of Virginia. ${ }^{15}$ In the context of the ACA, affiliations between HCs and local hospitals may increase as providers begin to form accountable care organizations (ACOs), which aim to combine hospitals, physicians, and other health care providers to provide highquality coordinated care. If ACOs provide new opportunities for HCs to develop and enhance relationships with local providers, HC's PCMH capability may improve.

In addition to census division, another regional characteristic - state support of PCMH activities - may explain some variation of PCMH capability in HCs. We found strong significant effects of $\mathrm{HC}$ location in a state with statesupported PCMH initiatives and PCMH payment by payers in the subgroup analyses among HCs with an EHR. State participation in PCMH initiatives such as legislation requiring larger payments to medical homes by insurers may encourage HCs to increase their PCMH activities. State support of PCMH activities may be particularly important to HCs, since most state activity involves the Medicaid program, which is the single largest payer for HCs.

A few other characteristics such as percent margin, annual patient volume, and percent minority patients were also significantly associated with PCMH capability. The effects were small based on the unit we used to measure the characteristics, but could be practically significant at the extremes. For 
example, after accounting for other characteristics (e.g. percent uninsured patients), percent minority patients was negatively associated with PCMH capability. Given the wide distribution of this characteristic (range $0.08-100 \%$, interquartile range 13.4-73.2\%), HCs that serve a larger proportion of minority patients may need additional support to increase PCMH capability compared to their counterparts that serve a smaller proportion of minority patients.

Our study has several limitations. First, the cross-sectional study design did not allow us to assess causal relationships between the measured characteristics and PCMH capability. For example, the association between hospital affiliation and PCMH score could be either because more types of hospital relationships provide the $\mathrm{HC}$ with higher capability to perform as a PCMH, or because higher PCMH capability affords the $\mathrm{HC}$ more opportunities to affiliate with local hospitals. Second, PCMH capability was assessed at the HC's largest site, whereas some characteristics were measured at the overall center level. Although the assessment of the largest site may reflect the $\mathrm{PCMH}$ capability of a $\mathrm{HC}$, some performance inconsistencies may exist between a $\mathrm{HC}$ and its largest site. Third, PCMH capability was assessed by HC leaders, whose subjective perception of organizational structures and clinical processes might deviate from those of frontline staff. Fourth, we did not have the data to measure certain potential characteristics of interest, such as the financial stability of the HC. Fifth, though our study response rate reached $70 \%$, HCs that were excluded from the analysis may differ systematically from those that were included (e.g. hospital affiliation), and thus our results are not necessarily generalizable to all HCs. Sixth, we assumed the same additive effect for each financial performance incentive type and each hospital affiliation type, which may not be true, because individual types may interact with each other. Finally, while our measure of PCMH capability was fairly comprehensive and was based on the predominant assessment available at the time it was developed, ${ }^{41}$ there are some aspects of the PCMH that our scale may not capture well, such as continuity of care or team functioning.

Overall, our study suggests that multiple characteristics are associated with PCMH capability in HCs. Because most HCs have an EHR in place $(97.7 \%$ HCs with EHR installed in 2014) ${ }^{36}$ we may focus on other features that were associated with PCMH capability, such as providing more types of financial performance incentives, supporting HC-hospital affiliations, and implementing state-level PCMH initiatives and $\mathrm{PCMH}$ payments. To perform as high-functioning PCMHs, it is important for HCs to have support from federal agencies, payers, states, and local communities. This study provides data to inform $\mathrm{HCs}$ and other stakeholders seeking to improve HC's PCMH capability.

Acknowledgments: The authors wish to acknowledge Sarah Kinsler, former Policy Specialist; Charles Townley, Project Director; and Mary Takach, MPH, RN, former Senior Program Director of the National Academy for State Health Policy, Portland, Maine, for their help on data consultation and preparation for one of the variables: state support of medical home activity in 2009.

This project was supported by the Commonwealth Fund (Grant 20080366). Dr. Chin was supported by the Chicago Center for Diabetes Translation Research (NIDDK P3O DK092949) and a National Institute of Diabetes and Digestive and Kidney Diseases (NIDDK) Midcareer Investigator Award in Patient-Oriented Research (NIDDK K24 DK071933). Mr. Nocon was supported by an Agency for Healthcare Research and Quality (AHRQ) training grant (AHRQ T32 HSOOOO84).

This manuscript was presented in abstract format at the AcademyHealth Annual Research Meeting on June 23, 2013, in Baltimore, Maryland; the National Association of Community Health Centers Community Health Institute \& EXPO on August 25, 2013, in Chicago, Ilinois; and the Midwest Region Society of General Internal Medicine meeting on September 13, 2013, in Chicago, Illinois.

Corresponding Author: Marshall H. Chin, MD, MPH; Section of General Internal Medicine, Department of Medicine, The University of Chicago, 5841 S. Maryland Ave., MC 2007, Room B216, Chicago, IL 60637, USA (e-mail: mchin@medicine.bsd.uchicago.edu).

\section{Compliance with Ethical Standards:}

Conflict of Interest: The authors declare that they have no conflict of interest.

\section{REFERENCES}

1. Health Resources and Service Administration. Health Center Data. Rockville, MD: Health Resources and Service Administration(HRSA); 2015. Available at: http://bphc.hrsa.gov/uds/datacenter.aspx. Accessed April 25, 2016.

2. Centers for Medicare and Medicaid Services. Federally Qualified Health Center Advanced Primary Care Practice Demonstration. Baltimore, MD: Centers for Medicare and Medicaid Services (CMS). Available at: http://www.cms.gov/ Medicare/Demonstration-Projects/DemoProjectsEvalRpts/Medicare-Demonstrations-Items/CMS1230557.html. Accessed April 25, 2016.

3. Health Resources and Service Administration. Patient Centered Medical Home-Facility Improvement (P-FI) Technical Assistance. Rockville, MD: Health Resources and Service Administration (HRSA). Available at: http:// bphc.hrsa.gov/programopportunities/fundingopportunities/pfi/index. html. Accessed April 25, 2016.

4. Health Resources and Service Administration. HRSA Accreditation and Patient-Centered Medical Home Recognition Initiative. Rockville, MD: Health Resources and Service Administration (HRSA). Available at: http://bphc.hrsa.gov/qualityimprovement/clinicalquality/accreditationpcmh/index.html. Accessed April 25, 2016.

5. Nielsen M, Langner B, Zema C, Hacker T, Grundy P. Benefits of implementing the primary care medical home: a review of cost \& quality results, 2012. Washington, D.C.: Patient-Centered Primary Care Collaborative (PCPCC); 2012. Available at: https://www.pcpcc.org/guide/benefitsimplementing-primary-care-medical-home. Accessed April 25, 2016.

6. Jackson GL, Powers BJ, Chatterjee R, et al. Improving patient care. The patient centered medical home. A systematic review. Ann Intern Med. 2013;158:169-78.

7. Nielsen M, Olayiwola N, Grundy P, Grumbach $\mathbf{K}$. The patient-centered medical home's impact on cost \& quality: an annual update of the evidence, 2012-2013. Washington, D.C.: Patient-Centered Primary Care Collaborative (PCPCC); 2014. Available at: https://www.pcpcc.org/resource/medical-homes-impact-cost-quality. Accessed April 25, 2016.

8. Nielsen M, Gibson A, Buelt L, Grundy P, Grumbach $\mathbf{K}$. The patient-centered medical home's impact on cost and quality, review of evidence, 2013-2014. Washington, D.C.: Patient-Centered Primary Care Collaborative (PCPCC); 2015. Available at: https://www.pcpcc.org/resource/patient-centeredmedical-homes-impact-cost-and-quality. Accessed April 25, 2016.

9. Rittenhouse DR, Casalino LP, Gillies RR, Shortell SM, Lau B. Measuring the medical home infrastructure in large medical groups. Health Aff. 2008;27:1246-58.

10. Rittenhouse DR, Casalino LP, Shortell SM, et al. Small and medium-size physician practices use few patient-centered medical home processes. Health Aff. 2011;30:1575-84. 
11. Wiley JA, Rittenhouse DR, Shortell SM, et al. Managing chronic illness: physician practices increased the use of care management and medical home processes. Health Aff (Millwood). 2015;34:78-86.

12. Hearld LR, Weech-Maldonado R, Asagbra OE. Variations in patientcentered medical home capacity: a linear growth curve analysis. Med Care Res Rev. 2013;70:597-620.

13. Hearld LR, Hearld KR, Hogan TH. Community-level sociodemographic characteristics and patient-centered medical home capacity. Adv Health Care Manag. 2014;16:23-50.

14. Goldberg DG, Kuzel AJ. Elements of the patient-centered medical home in family practices in Virginia. Ann Fam Med. 2009;7:301-8.

15. Goldberg DG, Mick SS. Medical home infrastructure: effect of the environment and practice characteristics on adoption in Virginia. Med Care Res Rev. 2010;67:431-49.

16. Casalino L, Gillies RR, Shortell SM, et al. External incentives, information technology, and organized processes to improve health care quality for patients with chronic diseases. JAMA. 2003;289:434-41.

17. Friedberg MW, Safran DG, Coltin KL, Dresser M, Schneider EC. Readiness for the patient-centered medical home: structural capabilities of Massachusetts primary care practices. J Gen Intern Med. 2009;24:162-9.

18. Friedberg MW, Coltin KL, Safran DG, Dresser M, Schneider EC. Medical home capabilities of primary care practices that serve sociodemographically vulnerable neighborhoods. Arch Intern Med. 2010;170:938-44.

19. Nelson KM, Helfrich C, Sun H, et al. Implementation of the patientcentered medical home in the Veterans health administration: associations with patient satisfaction, quality of care, staff burnout, and hospital and emergency department use. JAMA Intern Med. 2014;174:1350-8.

20. Zickafoose JS, Clark SJ, Sakshaug JW, Chen LM, Hollingsworth JM. Readiness of primary care practices for medical home certification. Pediatrics. 2013;131:473-82.

21. Solberg LI, Stuck LH, Crain AL, et al. Organizational factors and change strategies associated with medical home transformation. Am J Med Qual. 2015;30:337-44

22. Hollingsworth JM, Saint S, Sakshaug JW, Hayward RA, Zhang L, Mille DC. Physician practices and readiness for medical home reforms: policy, pitfalls, and possibilities. Health Serv Res. 2012;47(1 Pt 2):486-508.

23. Rittenhouse DR, Schmidt LA, Wu KJ, Wiley J. Incentivizing primary care providers to innovate: building medical homes in the post-Katrina New Orleans safety net. Health Serv Res. 2014;49:75-92.

24. Aysola J, Orav EJ, Ayanian JZ. Neighborhood characteristics associated with access to patient-centered medical homes for children. Health Aff (Millwood). 2011;30:2080-9.

25. Zickafoose JS, Gebremariam A, Davis MM. Medical home disparities for children by insurance type and state of residence. Matern Child Health J. 2012;16(Suppl 1):S178-87.

26. Knapp C, Woodworth L, Fernandez-Baca D, Baron-Lee J, Thompson L, Hinojosa M. Factors associated with a patient-centered medical home among children with behavioral health conditions. Matern Child Health J. 2013; 17:1658-64.
27. Birnberg JM, Drum ML, Huang ES, et al. Development of a safety net medical home scale for clinics. J Gen Intern Med. 2011;26:1418-25.

28. Health Resources and Service Administration. Uniform Data System (UDS) Resources. Rockville, MD: Health Resources and Service Administration(HRSA). Available at: http://bphc.hrsa.gov/datareporting/ reporting/index.html. Accessed April 25, 2016.

29. The Commonwealth Fund. The 2009 Commonwealth Fund National Survey of Federally Qualified Health Centers. New York, NY: The Commonwealth Fund; 2009. Available at: http://www.commonwealthfund.org/ interactives-and-data/surveys /2010/may/the-2009-commonwealthfund-national-survey-of-federally-qualified-health-centers. Accessed April $25,2016$.

30. United States Census Bureau. 2007-2011 American Community Survey 5Year Estimate. Washington D.C.: U.S. Census Bureau; 2012. Available at: http://www.census.gov/newsroom/releases/archives/news_conferences / 20121203_acs5yr.html. Accessed April 25, 2016.

31. Health Resources and Service Administration. Primary Care Service Areas Data Download-2007 (ZIP Code Basis). Rockville, MD: Health Resources and Service Administration(HRSA); 2009. Available at: http:// datawarehouse.hrsa.gov/data/datadownload/pcsa2007download.aspx. Accessed April 25, 2016.

32. Cutrona SL, Keitz SA. Home is where the patient is: a ground-level perspective on the patient-centered medical home. Med Care. 2015;53:387-8.

33. Bendel RB, Afifi AA. Comparison of stopping rules in forward "stepwise" regression. J Am Stat Assoc. 1977;72:46-53.

34. Shaffer JP. Multiple hypothesis testing. Annu Rev Psychol. 1995;46:561-84.

35. Jones EB, Furukawa MF. Adoption and use of electronic health records among federally qualified health centers grew substantially during 201012. Health Aff (Millwood). 2014;33:1254-61.

36. Health Resources and Service Administration. Electronic Health Record (EHR) Information. Rockville, MD: Health Resources and Service Administration(HRSA); 2015. Available at: http://bphc.hrsa.gov/uds/ datacenter.aspx?q=tehr\&year=2014\&state $=$. Accessed April 25, 2016.

37. Nocon RS, Sharma R, Birnberg JM, Ngo-Metzger Q, Lee SM, Chin MH. Association between patient-centered medical home rating and operating cost at federally funded health centers. JAMA. 2012;308:60-6.

38. Shi L, Lock DC, Lee DC, et al. Patient-centered medical home capability and clinical performance in HRSA-supported health centers. Med Care. 2015;53:389-95.

39. Zheng B. Summarizing the goodness of fit on generalized linear models for longitudinal data. Stat Med. 2000; 19:1265-75.

40. Kern LM, Edwards A, Kaushal R. The patient-centered medical home, electronic health records, and quality of care. Ann Intern Med. 2014;160:741-9.

41. National Committee for Quality Assurance. Standards and Guidelines for Physician Practice Connections ${ }^{\circledR}$ - Patient-Centered Medical Home (PPC$\mathrm{PCMH}^{\mathrm{TM}}$ ). Washington, D.C.: National Committee for Quality Assurance(NCQA); 2008. Available at: http://www.ncqa.org/Portals/0/Programs/Recognition/PCMH_Overview_Apr01.pdf. Accessed April 25, 2016. 